\title{
A CONCEPTUAL REVIEW OF THE TALENT MANAGEMENT AND EMPLOYEE RETENTION IN BANKING INDUSTRY
}

\author{
Mohammad Helal Uddin Akanda \\ Faculty of Business and Accountancy \\ Universiti Selangor (UNISEL), Shah Alam, Malaysia \\ E-mail: dd.napd@gmail.com \\ Abul Bashar Bhuiyan \\ Faculty of Business and Accountancy \\ Universiti Selangor (UNISEL), Shah Alam, Malaysia \\ Mokana Muthu Kumarasamy \\ Faculty of Business and Accountancy \\ Universiti Selangor (UNISEL), Shah Alam, Malaysia \\ Gunasegaran Karuppannan \\ Faculty of Education and Social Science \\ Universiti Selangor (UNISEL), Shah Alam, Malaysia
}

\begin{abstract}
The value of talent workers, talent management and talent retention has increased in the increasing economic circumstances of the world. Talented and devoted employees are often an integral part of every company. Smart, sophisticated, digitally literate, internationally astute and operationally agile businessmen are considered talented individuals. Talent management means that organisations have access to strategic planning with the best candidates with relevant expertise placed in the right place. Therefore, the aim of this study is to develop a conceptual model that explain the relationship between talent management and employee retention. The study will be used to accumulate empirical literature by the name of talent management and talent retention in different online database sources such as Google Scholars, Springer Link, Wiley, Science Direct, JSTOR, Emerald full text, Scopus, and EBSCO HOST, etc. The review findings of the study shown that any success or loss of a company mostly depends on the activities and survival of talented employees. The study also found that the retention of employees is one of the challenges that many public and private organisations face, has become an even greater challenge facing human resources professionals because there is a luxury of choice for talented candidates in the global job skills market. At the same time, there is a lack of research emphasizing only on banking industry. The proposed conceptual model depicts the significant effect of working environment and other dimensions of talent management and its effect on employee retention in banking industry.
\end{abstract}

Keywords: Talent Management, Employee Retention, Banking Industry, Working Environment. 


\section{INTRODUCTION}

Human resource management literature was virtually non-existent until the last decade, and while it has remained conceptually oriented, it is becoming increasingly empirically based. Jobs have been undervalued in talent management literature, despite their centrality. Dries (2013) emphasised the importance of developing new talent management techniques to capitalise on the growing emphasis on the psychological response of employees to talent management. Despite its rapid growth, the talent management literature continues to be fragmented and could greatly benefit from theoretical scaffolding. This is a grave matter of concern (Alferaih et al., 2018; Ashraf, 2020; Chinyio et al., 2018; Sun et al., 2019). The talent management debate continues. Talent management is the process of managing employees differently based on their relative ability to contribute to the organization's competitive advantage. The issue with this concept of talent is that it introduces two new requirements: human resource infrastructure and talent deployment across distinct roles and critical resources.

Talent management entails successfully placing the most qualified individuals in the appropriate positions. The employees will reap the full benefits of the company's talent. It affects businesses because many organisations consider talent management in order to ensure they hire the best candidates. In this way, talent management can have a significant impact on staff recruitment and retention (Ayodele et al., 2020; Tews et al., 2020; Watson et al., 2018). Since approximately 2000, talent management has grown in popularity. This is management at a time when entry into the Singapore labour market will be difficult. The subject of talent management has gained traction in both literature and business. This has been asserted by a number of individuals to be "much more critical than ever to organisational performance" and "one of the most critical industry metrics." Talent management necessitates processes that safeguard talent attraction, retention, and development. Talent recruitment is critical because it enables businesses to hire the best employees. Recognizing and developing talent enables businesses to identify employees who are capable of making meaningful impacts as executives in the near future. This strategy places a premium on developing societies with a high level of leadership talent (Ayodele et al., 2020; Tews et al., 2020; Watson et al., 2018).

Due to the enormous differential value provided by a skilled person, recent human resource analysis has tended to focus on skill retention rather than overall workforce retention. No organisation can fathom the dangers of losing a top star, even less to a competitor. At times, even a single person will alter the organization's course (Arasanmi \& Krishna, 2019). Mckinsey and Company emphasise the value of skilled staff by stating that a top software developer will write ten times the amount of available code than an average developer. Managing top talent has become a hot topic of debate for academics and human resource professionals in recent years. Managing skilled workers has been a herculean activity due to the combined pressures of population, workforce, and business factors. In this context, human resource professionals and experts argue for talent acquisition as a panacea for all talent-related challenges, and it has evolved over the past decade into a valuable human resource initiative for talent retention. Talent management, which encompasses the identification, growth, and cultivation of certain individuals that add significant value to an organisation, gains attention due to its assertion of lowering attrition of skilled workers, a serious concern for organisations (Buers et al., 2018; DiPietro et al., 2019; Jha, 2019). Although professionals and experts extol the wonders of talent management, the mechanism by which talent management results in increased employee satisfaction seems to be uncharted territory. 
Few studies have examined the relationship between talent acquisition strategies and improved talent retention rates. Like in all other recruitment tactic, talent management has little clear impact on an employee's retention conduct (Chaudhuri et al., 2020). To understand the role of talent management in employee engagement, it is critical to understand the mindset formed in talented employees that can affect their behaviour. The word "employee retention" is used in the article to refer to the retention of the organization's skilled or high potential employees on whom talent acquisition programmes are based. Additionally, amid a wealth of empirical studies from a variety of researchers, further research is needed to further explain the effects of talent management on employee retention. As such, the aim of this analysis is to establish a testable theory about the aspects of talent management and employee retention.

\section{What is Talent Management (TM)?}

\section{LITERATURE REVIEW}

Strategic talent management is concerned with the organisational management of employees defined as talent and their contribution to the organisation, which is itself a component of a broader strategy aimed at generating competitive advantage through human capital. Talent management is conducted to maximise an organization's overall efficiency or to serve as a competitive advantage. Concerned with the management of the firm's strategic human capital resources, which are viewed as rare, valuable, and difficult to replicate from the firm's resourcebased view (RBV), this practise of strategic workforce differentiation is expected to add value to the organisations that implement it, and doing so requires significant management effort and expense (Chang \& Busser, 2020; Dhanpat et al., 2019; DiPietro et al., 2019; Matongolo et al., 2018; Mukherjee et al., 2019). The overarching principle of talent management is to maximise the value of talent as a distinct resource for the benefit of the organisation. However, research on talent resource management approaches, such as talent decision-making and talent value development, has only recently begun. Given that only a small percentage of the workforce is classified as high potential, skilled employees are a scarce resource that organisations view as critical to their success. Organizations believe that investing in talent management can result in increased levels of human capital.

Talent Management (TM) is a term that is widely used today, but gained popularity in 1997 when Mckinsey \& Company coined the phrase 'War for talent' in reference to their research on talent management and practises. Since then, there has been an explosion of literature in the field of talent management, which continues to this day. While the increasing number of articles and books on the subject may lead one to believe that 'talent management' is a well-defined area of practise backed up by extensive research and a core set of principles, the majority of them lack empirical support. Due to the lack of a consistent definition and distinct conceptual boundaries, talent management is viewed as a complex and ever-evolving concept (Meyer \& Smith, 2000; Nuhu et al., 2016; Sablok et al., 2017; Sinclair-Maragh et al., 2017). Lewis and Heckman (2006) identified three distinct strains of thought surrounding the concept of talent management, including rebranding human resource management as talent management, focusing on the development of talent pools, and focusing on talent generically regardless of organisational boundaries or specific positions. Collings and Mellahi (2009) added a fourth stream that focuses on identifying critical positions rather than on identifying talented individuals.

Many organisations have renamed their human resource management system due to the novelty of the term talent management and its associated legitimacy. However, they fail to distinguish talent management from traditional human resource management, resulting in 
criticisms akin to old wine in a new bottle. Human resource management is a wide umbrella of numerous employee related practices, but talent management is a focused strategy which aims at high potential employees or talented employees (Ewerlin \& Süß, 2016; Su et al., 2020; Tian et al., 2020). It is important to understand the two main approaches to talent management when describing talent management: exclusive and inclusive approaches. The exclusive strategy is based on the principle of 'workforce distinction,' which views talent as an elite segment of the organization's employees that can make a difference in terms of organisational success. The egalitarian approach is often motivated by 'humanistic' considerations and implies that all organisational capital should be distributed equally among employees, since everybody in the organisation possesses potential 'talent.' These approaches to talent management evolved from a subject-matter perspective on talent. While an egalitarian approach can be enticing, the exclusive approach is the most common in human resource practise and is commonly supported in the literature. In this article, talent management is defined exclusively by Blass (2007), who describes it as the additional management mechanisms and resources made available to individuals in an organisation who are deemed to be 'talented.'

\section{Employee retention}

Employee retention has been a primary concern for many businesses in the modern era. Although recruiting capable individuals will still be critical, employee engagement is the most critical characteristic of a good human resources professional. (Steil et al., 2020) classified job productivity benefits as intrinsic and extrinsic. They note that intrinsic incentives are nonmaterial in nature, such as career advancement for employees, while extrinsic rewards are material in nature, such as bonuses or other cash compensation. Extrinsic rewards, the researcher observed, are critical for retaining talent in a winning environment. However, (Chaudhuri et al., 2020) suggest that extrinsic benefits are more effective at motivating employees because they foster loyalty and reciprocity.

\section{Dimensions of Employee Retention}

According to Hadi and Ahmed (2018), their research emphasised the importance of creating a diverse work atmosphere within leading and competing organisations in order to ensure the organization's success and achieve a competitive edge over other organisations. It is critical, thus, to hire and retain the best and most experienced employees whose work is critical (Hadi \& Ahmed, 2018). In another report, Das and Baruah (2013) concluded that so many factors impair employee retention and are unaffected by a single cause. Management must consider factors such as salaries and benefits, workplace stability, recruitment and promotion, supervisor support culture, work environment, and organisational justice, among others. Employee happiness and retention are the primary determinants of an organization's success, according to (Chang \& Busser, 2020; Marinakou \& Giousmpasoglou, 2019; Pandita \& Ray, 2018). The retention factor can be classified into three different categories: social, psychological, and physical. Employees also choose versatile job positions that enable them to apply their experience and see the results of their efforts, which aids in the preservation of scarce capital. Job characteristics comprise the behavioural portion of retention. The social factor refers to the relationships that employees have with other people, both internal and external. The physical dimension is comprised of working conditions and compensation. Walker (2001) identified seven factors that contribute to employee satisfaction: I recognise and reward performance by (ii) challenging jobs, (iii) opportunities for advancement and learning, (iv) an inviting organisational culture, (v) supportive interactions 
with colleagues, (vi) a balanced balance between professional and personal life, and (vii) effective contact. Taken together, these reflect a compilation of workplace standards and practises that may be interpreted as inviting employee engagement. Three variables were used to categorise the retention factors: power, accomplishment, and association. Superiority and social impact are indicators of power. It denotes achievement when personal success exceeds predetermined standards, while association refers to the formation and strengthening of social relationships. Gireesh (2014) defined the following five dimensions of employee retention in another study:

\section{Job Support and Recognition}

This axis is composed of eight variables. The factors are as follows: manager praise for productive work, recognition and appreciation of success, effective counselling and mentoring, regular and demanding work performance assessments, participation in decision-making, boss approval, and care for employees' personal and professional needs. The reasons mentioned above are the most important in Kerala when it comes to increasing internal encouragement for workers in the BPO industry (Jha, 2019). Numerous experiments have corroborated this finding.

\section{Compensation and Career Growth}

This aspect is comprised of six variables: management's sincere interest in employee ideas to improve service quality, payment through job, success, the feasibility of the existing granting scheme, trust in achieving career objectives, the company's position in cultivating career development, and the employee's desire to proceed and extend with the organisation. Numerous previous experiments have corroborated this finding.

\section{Organizational Culture}

This axis is composed of four variables. The factors are: position-related autonomy, the prevalence of a positive social environment, departmental unity, and acceptance of constructive employee feedback about their sense of respect in the workplace. Numerous reports corroborate this conclusion.

\section{Work-compatibility}

This axis is composed of two variables. The factors are the job's ability to foster a sense of accomplishment and self-esteem, and the organization's commitment to maintaining workers' work-life balance. Numerous previous experiments have corroborated this finding.

\section{Autonomy and Independence}

This axis is composed of two variables. The following factors are taken into account: the existence of the required freedom to perform the work and the pleasure associated with performing the job. According to Miklós Pakurár et al., banks must meet their customers' needs in order to achieve sustainable development (2019). The SERVQUAL model was revised for this study, which can be used to measure customer loyalty and the impact of service quality dimensions. In Jordanian banks, these dimensions were as follows: tangible, responsiveness, empathy, assurance, performance, access, financial aspect, and employee customer satisfaction skills. 


\section{Talent Management on Employee Retention}

Attracting and retaining expertise for a sustainable period of time is a significant obstacle facing Iranian public and private corporations in all industries today. Improved workforce recruiting and retention are among the results of a well-executed talent acquisition approach. Retention of knowledge staff may provide an organisation with a strategic edge (Sigler, 1999). One of the most significant advantages of talent acquisition is the impact on recruiting and retaining valuable staff. According to Lalitha (2012), the most significant problem facing human resource professionals in the global economy is employee retention. The author recommended some successful engagement techniques and procedures, including employer branding, modifying recruiting processes, talent acquisition, and termination interviews. et al. et al. (2008) examined the impact of talent management on employee recruiting, retention, and involvement in hospitality organisations in their research "A strategy for optimising employee recruitment, retention, and engagement within hospitality organisations." According to the report, the advantages of a successful talent acquisition approach include increased employee recruiting and retention rates, as well as increased employee participation. These results have been linked to an increase in operating and financial efficiency. et Plansoongnern al. (2011) examined workforce recruitment practises and employee motivation in three of Thailand's largest cement firms. The study discovered that robust talent management planning, management support, organisational unity, work-life balance, and other environmental and organisational factors all play a role in retaining talent staff. Tiwari et al. (2013) examined talent management strategies and practises, as well as their impact on employee retention and the effectiveness of their implementation. The study discovered that while employee age is unrelated to satisfaction, employee experience does have an effect on employee satisfaction with talent management activities. Walsh and Taylor (2007) disclosed in their article "Developing in-house jobs and maintaining management expertise" that while pay and work-life balance are critical, management retention is impacted by the lack of opportunities for technical and organisational growth and development. Ross (2005) demonstrated that the retention battle begins during the selection process, with organisations seeking workers whose skills and desires align with the organization's short- and long-term goals. Altrnaz et al. (2013) examined the influence of talent management on organisational confidence in Ankara hotels and discovered that positively influencing mid-level and senior hotel executives' views of talent management has a positive effect on organisational trust. The study is being conducted to better understand organisations' talent management strategies and their impact on employee retention through the mediating effect of organisational confidence. The aim of this survey is to determine if talent management practises have an impact on employee trust and the organization's labour retention rate.

\section{RESEARCH METHOD}

This current thesis summarised prior research on employee performance and retention in order to summarise it and create a distinct phenomenon. This thesis serves as a reference, as looking for and selecting pertinent literature was the initial stage. The foregoing is a summary of the literature collection procedure, including (a) the source of the publications, (b) the time period covered by the research, (c) who conducted the search, (d) how the literature was collected, (e) the final number of articles chosen, and (f) the rationale for the papers selected.

The current thesis gathered evidence for the study by consulting 30 academic papers. The researcher attempted to extract as many papers as possible that were important. The study was performed in December 2016 and included the aforementioned areas. To gain a thorough 
understanding of the topic, this thesis incorporates peer-reviewed academic papers written in English. The analysis of literature method used in this thesis is an appropriate method for identifying and synthesising the existing body of literature on a particular phenomenon.

\section{RESULTS AND DISCUSSIONS}

Thirty research papers were reviewed in total. Table 1 summarises the literature in chronological order. The overview includes the author's name, the article's purpose/objectives, sample data facts, and main findings/conclusions.

\begin{tabular}{|c|c|c|c|c|}
\hline Author & Objectives & Method & Variables & Key findings \\
\hline $\begin{array}{l}\text { (Yogalakshmi \& } \\
\text { Supriya, 2020) }\end{array}$ & $\begin{array}{l}\text { In the current } \\
\text { report, a } \\
\text { measure to } \\
\text { classify the } \\
\text { employee was } \\
\text { developed and } \\
\text { validated. This } \\
\text { is a long- } \\
\text { standing void } \\
\text { that scholars in } \\
\text { this area have } \\
\text { established. }\end{array}$ & $\begin{array}{l}\text { Three hundred } \\
\text { and two of our } \\
\text { staff agreed to } \\
\text { take part in the } \\
\text { assessment, } \\
\text { and completed } \\
\text { the 22-item } \\
\text { questionnaire. }\end{array}$ & $\begin{array}{l}\text { Calling } \\
\text { orientation } \\
\text { Critical insight } \\
\text { Continuous } \\
\text { learning } \\
\text { Collaboration } \\
\text { Cohesiveness } \\
\text { Challenge } \\
\text { drive }\end{array}$ & $\begin{array}{l}\text { the thesis provided a } \\
\text { six- or six-factor, } \\
\text { rather than a one- } \\
\text { dimensional, } \\
\text { framework for the } \\
\text { concepts } 66.8 \% \text { of } \\
\text { observed variation } \\
\text { was explained by } \\
\text { these variables. the } \\
\text { existence of all six } \\
\text { dimensions, which } \\
\text { are all of } \\
\text { importance in } \\
\text { creating and } \\
\text { maintaining good } \\
\text { processes: they are } \\
\text { defined as: variety } \\
\text { of ideas, logical } \\
\text { thinking, teamwork, } \\
\text { cohesion, and } \\
\text { motivation. }\end{array}$ \\
\hline (Gupta, 2019) & $\begin{array}{l}\text { The aim of this } \\
\text { study is to } \\
\text { decide whether } \\
\text { perceptions of } \\
\text { organisational } \\
\text { support (ORG) } \\
\text { are connected to } \\
\text { Generation Y } \\
\text { employees' } \\
\text { intent to leave } \\
\text { their } \\
\text { employment. }\end{array}$ & $\begin{array}{l}\text { The results of } \\
\text { the } \\
\text { questionnaires } \\
\text { (n } 825 \text { were } \\
\text { sent via e-mail } \\
\text { to the } \\
\text { participants, } \\
\text { who had a } \\
\text { response rate } \\
\text { of } 322 \\
\text { participants } \\
\text { who } \\
\text { responded out } \\
\text { of } 322(39 \% \\
\text { of them). } 284\end{array}$ & $\begin{array}{l}\text { Talent } \\
\text { Management } \\
\text { Practice, } \\
\text { Perceived } \\
\text { Organizational } \\
\text { Support } \\
\text { Perceived } \\
\text { supervisor } \\
\text { support } \\
\text { Intention to } \\
\text { leave }\end{array}$ & $\begin{array}{l}\text { the results obtained } \\
\text { from the Pearson } \\
\text { correlations showed } \\
\text { a significant } \\
\text { association between } \\
\text { the TMP and the } \\
\text { PCA to be positive. } \\
\text { It was discovered } \\
\text { that perceived boss } \\
\text { assistance was } \\
\text { shown to be } \\
\text { unrelated to TMP in } \\
\text { that a leave attempt } \\
\text { to remain was seen } \\
\text { regardless of }\end{array}$ \\
\hline
\end{tabular}




\begin{tabular}{|c|c|c|c|c|}
\hline & & $\begin{array}{l}\text { questionnaires } \\
\text { remained after } \\
\text { deleting the } 8 \\
\text { questionnaires } \\
\text { that could be } \\
\text { used for } \\
\text { further study. } \\
\text { Participants } \\
\text { were assumed } \\
\text { to be able to } \\
\text { read, write and } \\
\text { speak English. }\end{array}$ & & $\begin{array}{l}\text { whether or not it } \\
\text { was considered } \\
\text { necessary. These } \\
\text { findings reinforce } \\
\text { the assumption that } \\
\text { having a good boss } \\
\text { impacts workers' } \\
\text { appraisal of the } \\
\text { organization's } \\
\text { behaviour. }\end{array}$ \\
\hline $\begin{array}{l}\text { (Marinakou \& } \\
\text { Giousmpasoglou, } \\
\text { 2019) }\end{array}$ & $\begin{array}{l}\text { This paper } \\
\text { defines the issue } \\
\text { of staff } \\
\text { acquisition in } \\
\text { the luxury hotel } \\
\text { industry and } \\
\text { puts an } \\
\text { emphasis on } \\
\text { approaches to } \\
\text { retain staff. }\end{array}$ & $\begin{array}{l}\text { semi- } \\
\text { structured } \\
\text { interviews } \\
\text { were } \\
\text { conducted } \\
\text { with } 27 \\
\text { managers in } \\
\text { four countries } \\
\text { using a } \\
\text { qualitative } \\
\text { approach, } \\
\text { followed by } \\
\text { meetings with } \\
\text { decision } \\
\text { makers in four } \\
\text { of luxury } \\
\text { hotels }\end{array}$ & $\begin{array}{l}\text { Work } \\
\text { environment; } \\
\text { Supervisor } \\
\text { support } \\
\text { Carrier } \\
\text { development. }\end{array}$ & $\begin{array}{l}\text { According to that } \\
\text { view, talent is } \\
\text { described as those } \\
\text { who "go beyond } \\
\text { and beyond the call } \\
\text { of duty". lobbies in } \\
\text { luxurious hotels } \\
\text { provide a caring, } \\
\text { family-oriented and } \\
\text { welcoming } \\
\text { atmosphere, skill } \\
\text { retention initiatives, } \\
\text { employee benefits, } \\
\text { growth and } \\
\text { development, and } \\
\text { preparation. In a } \\
\text { focus on employee, } \\
\text { as well as company- } \\
\text { wide (or } \\
\text { organisational) } \\
\text { talent, it is } \\
\text { suggested that the } \\
\text { company employ an } \\
\text { exclusive (or } \\
\text { inclusory) approach }\end{array}$ \\
\hline (Ashraf, 2019) & $\begin{array}{l}\text { This paper seeks } \\
\text { to look at the } \\
\text { link between } \\
\text { working } \\
\text { conditions and } \\
\text { faculty attrition } \\
\text { in the private } \\
\text { sector, as well } \\
\text { as quality issues }\end{array}$ & $\begin{array}{l}\text { To achieve } \\
\text { these goals, } \\
512 \text { data were } \\
\text { gathered } \\
\text { through } \\
\text { random } \\
\text { sample survey } \\
\text { of faculty } \\
\text { members from }\end{array}$ & $\begin{array}{l}\text { Working } \\
\text { condition, } \\
\text { Faculty } \\
\text { retention } \\
\text { Quality } \\
\text { education }\end{array}$ & $\begin{array}{l}\text { Additionally, the } \\
\text { findings show the } \\
\text { Muslow Hierarchy } \\
\text { of inspiration at } \\
\text { work again and } \\
\text { reinforce its validity } \\
\text { in private } \\
\text { universities. When } \\
\text { more and more }\end{array}$ \\
\hline
\end{tabular}




\begin{tabular}{|c|c|c|c|c|}
\hline & $\begin{array}{l}\text { in Bangladesh's } \\
\text { universities. }\end{array}$ & $\begin{array}{l}\text { the country's } \\
\text { private } \\
\text { universities. } \\
\text { Structural } \\
\text { modelling was } \\
\text { used to } \\
\text { explore the } \\
\text { correlations } \\
\text { among the } \\
\text { variables. }\end{array}$ & & $\begin{array}{l}\text { empirical analyses } \\
\text { of the } \\
\text { characteristics of } \\
\text { teachers and how } \\
\text { they influence their } \\
\text { performance are } \\
\text { conducted, the } \\
\text { hypothesis is } \\
\text { refined and } \\
\text { validated, assisting } \\
\text { the administration } \\
\text { in management } \\
\text { strategies for human } \\
\text { resource activities. }\end{array}$ \\
\hline $\begin{array}{l}\text { (Rombaut \& } \\
\text { Guerry, 2020) }\end{array}$ & $\begin{array}{l}\text { In order to } \\
\text { ensure company } \\
\text { stability, the } \\
\text { primary } \\
\text { objective of } \\
\text { employee } \\
\text { engagement is } \\
\text { to keep talented } \\
\text { individuals from } \\
\text { departing. The } \\
\text { concern that } \\
\text { emerges in this } \\
\text { context is, } \\
\text { Which retention } \\
\text { tactics really } \\
\text { impact } \\
\text { workforce } \\
\text { turnover and } \\
\text { with the types of } \\
\text { workers do they } \\
\text { work? }\end{array}$ & $\begin{array}{l}\text { To gain an } \\
\text { understanding } \\
\text { of various } \\
\text { retention } \\
\text { techniques, } \\
\text { several studies } \\
\text { are examined. } \\
\text { Finally, the } \\
\text { paper } \\
\text { describes how } \\
\text { to develop an } \\
\text { uplift model } \\
\text { for assessing } \\
\text { the various } \\
\text { approaches to } \\
\text { evaluating HR } \\
\text { data. A } \\
\text { random forest } \\
\text { algorithm } \\
\text { employs the } \\
\text { random } \\
\text { sampling } \\
\text { model; in } \\
\text { contrast, } \\
\text { personal care } \\
\text { is based on } \\
\text { machine } \\
\text { learning. }\end{array}$ & $\begin{array}{l}\text { Recognition } \\
\text { Compensation } \\
\text { Training and } \\
\text { development } \\
\text { Flexibility } \\
\text { Effective } \\
\text { selection } \\
\text { Empowerment } \\
\text { Job security }\end{array}$ & $\begin{array}{l}\text { The impact of } \\
\text { retention tactics on } \\
\text { employee turnover } \\
\text { is researched with } \\
\text { evidence. Overall, } \\
\text { retention tactics } \\
\text { have good results } \\
\text { but incentives and } \\
\text { versatility do not. } \\
\text { For personalised } \\
\text { learning, however, } \\
\text { however, it is } \\
\text { expected that the } \\
\text { individual response } \\
\text { can be calculated. } \\
\text { Because of this, } \\
\text { workers with the } \\
\text { most potential } \\
\text { treatment effects } \\
\text { will be profiled. }\end{array}$ \\
\hline $\begin{array}{l}\text { (Gandy et al., } \\
\text { 2018) }\end{array}$ & $\begin{array}{l}\text { The aim of this } \\
\text { paper is to } \\
\text { investigate the } \\
\text { advantages of }\end{array}$ & $\begin{array}{l}\text { For all } \\
\text { incoming } \\
\text { employees and } \\
\text { existing }\end{array}$ & $\begin{array}{l}\text { Age, } \\
\text { Gender, } \\
\text { Type of } \\
\text { contract }\end{array}$ & $\begin{array}{l}\text { There was variance } \\
\text { in age, gender, as } \\
\text { well as types of } \\
\text { contract, for }\end{array}$ \\
\hline
\end{tabular}




\begin{tabular}{|c|c|c|c|c|}
\hline & $\begin{array}{l}\text { detail staff } \\
\text { research in } \\
\text { Higher } \\
\text { Education's } \\
\text { dynamic change } \\
\text { environment. }\end{array}$ & $\begin{array}{l}\text { workers, there } \\
\text { was an } \\
\text { analysis of the } \\
\text { difference in } \\
\text { the numbers } \\
\text { that stayed and } \\
\text { left. Overall } \\
\text { shapes and } \\
\text { oddities were } \\
\text { brought to the } \\
\text { fore on the } \\
\text { Nomograph of } \\
\text { Inverted. } \\
\text { Other traits } \\
\text { tested for were } \\
\text { age, ethnicity, } \\
\text { tenure, and } \\
\text { employment } \\
\text { status. }\end{array}$ & & $\begin{array}{l}\text { research } \\
\text { professionals, and } \\
\text { this resulted in } \\
\text { extensive turnover } \\
\text { (influenced by the } \\
\text { use of fixed-term } \\
\text { contracts). Older } \\
\text { workers can leave a } \\
\text { firm for more } \\
\text { established firms if } \\
\text { offered, though, so } \\
\text { it is possible that } \\
\text { they will remain if } \\
\text { there are longer- } \\
\text { term prospects for } \\
\text { job growth and } \\
\text { advancement. } \\
\text { useable mechanisms } \\
\text { are used to discover } \\
\text { and maintain good } \\
\text { talent, } \\
\text { accommodate life- } \\
\text { span requirements, } \\
\text { and answer } \\
\text { emerging problems } \\
\text { such as gender } \\
\text { inequity }\end{array}$ \\
\hline $\begin{array}{l}\text { (Maurya \& } \\
\text { Agarwal, 2018) }\end{array}$ & $\begin{array}{l}\text { The aim of this } \\
\text { paper is to study } \\
\text { how talent } \\
\text { acquisition } \\
\text { strategies affect } \\
\text { perceptions. }\end{array}$ & $\begin{array}{l}\text { The results are } \\
\text { being } \\
\text { presented } \\
\text { using } \\
\text { quantitative } \\
\text { design; a } \\
\text { questionnaire } \\
\text { was used to } \\
\text { determine } \\
\text { employer } \\
\text { talent } \\
\text { acquisition } \\
\text { and brand } \\
\text { architecture. } \\
\text { More than } 100 \\
\text { executives } \\
\text { from different } \\
\text { iron and coal } \\
\text { mines in the }\end{array}$ & $\begin{array}{l}\text { Talent } \\
\text { management } \\
\text { mindset, } \\
\text { Work life } \\
\text { balance, } \\
\text { Remunerations, } \\
\text { Attract and } \\
\text { recruit talent } \\
\text { Identifies talent } \\
\text { from } \\
\text { employees. }\end{array}$ & $\begin{array}{l}\text { According to the } \\
\text { findings, } \\
\text { organisational } \\
\text { management is } \\
\text { highly and } \\
\text { significantly related } \\
\text { to perceptions of } \\
\text { branding. } \\
\text { Regression found } \\
\text { that among the eight } \\
\text { dimensions of } \\
\text { employee } \\
\text { engagement, the } \\
\text { factors that can be } \\
\text { predicted by } \\
\text { organisations are } \\
\text { compensation which } \\
\text { work-life balance, } \\
\text { and manages talent }\end{array}$ \\
\hline
\end{tabular}




\begin{tabular}{|c|c|c|c|c|}
\hline & & $\begin{array}{l}\text { data are } \\
\text { obtained from } \\
\text { located in the } \\
\text { Indian } \\
\text { subcontinent. } \\
\text { At the end of } \\
\text { this, } 197 \\
\text { answers were } \\
\text { available for } \\
\text { review. } \\
\text { Multiple } \\
\text { regression } \\
\text { analysis was } \\
\text { employed to } \\
\text { assess the } \\
\text { hypothesis that } \\
\text { hypoxia was } \\
\text { caused by } \\
\text { anoxia. }\end{array}$ & & $\begin{array}{l}\text { well is motivating } \\
\text { employees. }\end{array}$ \\
\hline $\begin{array}{l}\text { (Al-Weshah, } \\
\text { 2019) }\end{array}$ & $\begin{array}{l}\text { The aim of this } \\
\text { research is to } \\
\text { better } \\
\text { understand the } \\
\text { significance of } \\
\text { IM activities on } \\
\text { employee } \\
\text { productivity in } \\
\text { Jordanian } \\
\text { hospitals. in this } \\
\text { analysis, four } \\
\text { variables are } \\
\text { studied: } \\
\text { workers' ability } \\
\text { to become more } \\
\text { empowered, } \\
\text { company } \\
\text { engagement, job } \\
\text { climate, } \\
\text { information- } \\
\text { sharing, and } \\
\text { company } \\
\text { processes. }\end{array}$ & $\begin{array}{l}\text { Quantitative } \\
\text { analysis is } \\
\text { used to gather } \\
\text { data. per day } \\
200 \text { surveys } \\
\text { are provided } \\
\text { to those who } \\
\text { are assigned in } \\
\text { Jordanian } \\
\text { hospitals to do } \\
\text { their own self- } \\
\text { administered. } \\
\text { an answer rate } \\
\text { of } 81 \text { percent. }\end{array}$ & $\begin{array}{l}\text { Employees } \\
\text { empowerment, } \\
\text { employees } \\
\text { motivation, } \\
\text { information } \\
\text { sharing and } \\
\text { work } \\
\text { environment. }\end{array}$ & $\begin{array}{l}\text { The conclusion of } \\
\text { this analysis is that } \\
\text { there is a notable } \\
\text { influence of IM. } \\
\text { Work commitment, } \\
\text { though, has the } \\
\text { greatest influence } \\
\text { on employee } \\
\text { motivation. }\end{array}$ \\
\hline $\begin{array}{l}\text { (Tafti et al., } \\
\text { 2017) }\end{array}$ & $\begin{array}{l}\text { This paper is } \\
\text { intended to } \\
\text { show the } \\
\text { complications of }\end{array}$ & $\begin{array}{l}\text { To do this, a } \\
\text { certain kind of } \\
\text { discovery } \\
\text { method has }\end{array}$ & $\begin{array}{l}\text { structural } \\
\text { success factors, } \\
\text { environmental } \\
\text { success factors }\end{array}$ & $\begin{array}{l}\text { As a result of the } \\
\text { study, we had } \\
\text { developed } \\
\text { frameworks for }\end{array}$ \\
\hline
\end{tabular}




\begin{tabular}{|c|c|c|c|c|}
\hline & $\begin{array}{l}\text { talent } \\
\text { acquisition as } \\
\text { well as well as } \\
\text { the possible } \\
\text { solutions in the } \\
\text { automotive } \\
\text { industries in } \\
\text { Iran. }\end{array}$ & $\begin{array}{l}\text { been applied, a } \\
\text { holistic } \\
\text { approach has } \\
\text { been used. The } \\
\text { study was } \\
\text { conducted on } \\
15 \\
\text { management } \\
\text { personnel in } \\
\text { automotive } \\
\text { industries. We } \\
\text { ran the data } \\
\text { analysis using } \\
\text { the coding } \\
\text { process, and } \\
\text { then extracted } \\
\text { the minor and } \\
\text { main contexts } \\
\text { for } \\
\text { development } \\
\text { of the } \\
\text { framework. }\end{array}$ & $\begin{array}{l}\text { and finally } \\
\text { managerial } \\
\text { success factors }\end{array}$ & $\begin{array}{l}\text { identifying both } \\
\text { threats and } \\
\text { opportunities, and } \\
\text { problems in } \\
\text { management, four } \\
\text { divisions emerged: } \\
\text { structural, } \\
\text { environmental, } \\
\text { behavioural, and } \\
\text { finally, managerial. } \\
\text { Additionally, there } \\
\text { were organised into } \\
\text { three major } \\
\text { categories that were } \\
\text { structural, } \\
\text { environmental, and } \\
\text { managerial growth } \\
\text { drivers in talent } \\
\text { management. }\end{array}$ \\
\hline $\begin{array}{l}\text { (Alferaih et al., } \\
\text { 2018) }\end{array}$ & $\begin{array}{l}\text { the aim of this } \\
\text { paper is to } \\
\text { examine the } \\
\text { critical success } \\
\text { factors } \\
\text { discussed in the } \\
\text { talent } \\
\text { management } \\
\text { literature and } \\
\text { any other ones } \\
\text { that could be } \\
\text { affecting } \\
\text { employees' } \\
\text { decision to leave }\end{array}$ & $\begin{array}{l}\text { Employees at } \\
\text { a high-level } \\
\text { positions in 5- } \\
\text { star hotels } \\
\text { from all over } \\
\text { the Saudi } \\
\text { Arabia took } 5 \\
\text { cities } \\
\text { responded to a } \\
\text { detailed } \\
\text { survey with } \\
\text { the correct } \\
\text { return rate of } \\
\text { more than } 600 \\
\text { correct } \\
\text { answers. }\end{array}$ & $\begin{array}{l}\text { Talent } \\
\text { retention } \\
\text { Turnover, } \\
\text { Turnover } \\
\text { intention, } \\
\text { Extrinsic } \\
\text { reward Talent } \\
\text { Talent } \\
\text { engagement } \\
\text { Organisational } \\
\text { Organisational } \\
\text { commitment, } \\
\text { Job satisfaction } \\
\text { Role conflict }\end{array}$ & $\begin{array}{l}\text { Help for the nine } \\
\text { hypotheses to } \\
\text { evaluate the } \\
\text { relationships was } \\
\text { included in all of } \\
\text { the theories made } \\
\text { up of the seven } \\
\text { constructs. } 68 \% \text { of } \\
\text { variation in talent } \\
\text { turnover can be } \\
\text { explained by the } \\
\text { modelling } \\
\text { technique. }\end{array}$ \\
\hline $\begin{array}{l}\text { (Mukherjee et } \\
\text { al., 2019) }\end{array}$ & $\begin{array}{l}\text { In addition to } \\
\text { the requirements } \\
\text { of researchers, } \\
\text { the project has } \\
\text { its sights set on }\end{array}$ & $\begin{array}{l}\text { The self- } \\
\text { administered } \\
\text { questionnaire } \\
\text { used the } \\
\text { Multistage }\end{array}$ & $\begin{array}{l}\text { job security, } \\
\text { autonomy, } \\
\text { work-life } \\
\text { balance, } \\
\text { culture and }\end{array}$ & $\begin{array}{l}\text { People employed in } \\
\text { the Indian public } \\
\text { sector can retain } \\
\text { their talents if they } \\
\text { are able to be fairly }\end{array}$ \\
\hline
\end{tabular}




\begin{tabular}{|c|c|c|c|c|}
\hline & \begin{tabular}{|l} 
seeking \\
consistencies \\
and distinctions \\
between groups \\
of PSU workers \\
based on their \\
key \\
contributions.
\end{tabular} & $\begin{array}{l}\text { sampling } \\
\text { approach to } \\
\text { capture } \\
\text { information } \\
\text { from } 472 \text { of } \\
\text { organisations, } \\
\text { with Simple } \\
\text { sampling } \\
\text { methods from } \\
\text { among the } \\
\text { remainder. } \\
\text { Findings from } \\
\text { logistic } \\
\text { regression, } \\
\text { MANOVA, } \\
\text { and post- } \\
\text { hocclusion in } \\
\text { SPS20 } \\
\text { revealed } \\
\text { differences. }\end{array}$ & $\begin{array}{l}\text { climate, career } \\
\text { growth, } \\
\text { leadership style } \\
\text { and support, } \\
\text { training and } \\
\text { development } \\
\text { and reward, } \\
\text { recognition and } \\
\text { pay. }\end{array}$ & $\begin{array}{l}\text { compensated, have } \\
\text { an opportunity for } \\
\text { promotion, have } \\
\text { personal dignity, } \\
\text { and enjoy working } \\
\text { conditions that } \\
\text { encourage } \\
\text { ingenuity. There is a } \\
\text { notable correlation } \\
\text { between age and job } \\
\text { security, but there is } \\
\text { also an important } \\
\text { distinction between } \\
\text { the two. Job } \\
\text { security and relative } \\
\text { employability are } \\
\text { identical for key } \\
\text { personnel. These } \\
\text { results have shown } \\
\text { that common } \\
\text { retention } \\
\text { approaches are } \\
\text { much more } \\
\text { successful than } \\
\text { coming up with a } \\
\text { new strategy to keep } \\
\text { workers. }\end{array}$ \\
\hline (Jha, 2019) & $\begin{array}{l}\text { The aim of this } \\
\text { paper is to } \\
\text { investigate the } \\
\text { connection } \\
\text { between } \\
\text { empowerment } \\
\text { (which I define } \\
\text { as the positive } \\
\text { force that gives } \\
\text { employees self- } \\
\text { motivation and } \\
\text { satisfaction) and } \\
\text { job security } \\
\text { (EPER). }\end{array}$ & $\begin{array}{l}\text { To analyse } \\
\text { those who } \\
\text { participated in } \\
\text { the report, it } \\
\text { was necessary } \\
\text { to examine } \\
\text { their roles in } \\
\text { the industry. A } \\
\text { larger } \\
\text { sampling size } \\
\text { was studied to } \\
\text { an even } \\
\text { greater extent, } \\
\text { to } 337 . \\
\text { Routine } \\
\text { surveys were } \\
\text { done. } \\
\text { Involuntary } \\
\text { mediation }\end{array}$ & $\begin{array}{l}\text { psychological } \\
\text { safety (PS) } \\
\text { Employee } \\
\text { retention (ER) } \\
\text { Psychological } \\
\text { empowerment } \\
\text { (PE), } \\
\text { Abusive } \\
\text { leadership }\end{array}$ & $\begin{array}{l}\text { This research } \\
\text { showed a combative } \\
\text { and domineering } \\
\text { leadership dynamic } \\
\text { in the interaction } \\
\text { between PS and PE. } \\
\text { One finding was } \\
\text { that the mediation } \\
\text { impact ofPS and ER } \\
\text { partnership was } \\
\text { important. The more } \\
\text { powerful a } \\
\text { leadership style } \\
\text { was, the worse the } \\
\text { partnership is. }\end{array}$ \\
\hline
\end{tabular}




\begin{tabular}{|c|c|c|c|c|}
\hline & & $\begin{array}{l}\text { sought to } \\
\text { determine the } \\
\text { effect of } \\
\text { bullying on } \\
\text { productivity. }\end{array}$ & & \\
\hline $\begin{array}{l}\text { (Steil et al., } \\
2020)\end{array}$ & $\begin{array}{l}\text { It seeks to } \\
\text { determine the } \\
\text { connection } \\
\text { between a } \\
\text { workforce's } \\
\text { willingness to } \\
\text { retain or leave } \\
\text { technological } \\
\text { employers based } \\
\text { on the amount } \\
\text { of learning } \\
\text { opportunities } \\
\text { and intentions to } \\
\text { remain in them. }\end{array}$ & $\begin{array}{l}\text { This is a } \\
\text { thorough } \\
\text { examination of } \\
440 \text { members } \\
\text { of a } \\
\text { technology- } \\
\text { focused } \\
\text { enterprise. }\end{array}$ & $\begin{array}{l}\text { perceived } \\
\text { learning } \\
\text { opportunities, } \\
\text { behavioral } \\
\text { intentions to } \\
\text { voluntarily stay } \\
\text { or leave }\end{array}$ & $\begin{array}{l}\text { The people who } \\
\text { viewed a company } \\
\text { as offering training } \\
\text { for the future had a } \\
\text { significant } \\
\text { correlation with } \\
\text { desire to remain, } \\
\text { and those who } \\
\text { perceived it as a } \\
\text { burden had a } \\
\text { significant } \\
\text { correlation to leave. } \\
\text { It was discovered } \\
\text { that there was no } \\
\text { correlation between } \\
\text { prospects for } \\
\text { learning and } \\
\text { retention. For this } \\
\text { reason, the link } \\
\text { between the } \\
\text { technician's belief in } \\
\text { his/her prospects for } \\
\text { improvement and } \\
\text { continued } \\
\text { employment of the } \\
\text { job is also near zero. }\end{array}$ \\
\hline $\begin{array}{l}\text { (Wikström et al., } \\
\text { 2018) }\end{array}$ & $\begin{array}{l}\text { The crux of this } \\
\text { research lies in } \\
\text { capturing, } \\
\text { codifying, and } \\
\text { then } \\
\text { internalising } \\
\text { information - } \\
\text { that is, finding } \\
\text { new ways to get } \\
\text { older workers to } \\
\text { integrate the } \\
\text { know-how into } \\
\text { their } \\
\text { organisations. } \\
\text { This paper is }\end{array}$ & $\begin{array}{l}\text { Senior } \\
\text { employees of } \\
\text { a Swedish } \\
\text { corporation } \\
\text { conducted this } \\
\text { investigation } \\
\text { centred on the } \\
\text { region. }\end{array}$ & $\begin{array}{l}\text { knowledge } \\
\text { capture, } \\
\text { knowledge } \\
\text { codification } \\
\text { and } \\
\text { internalising of } \\
\text { knowledge }\end{array}$ & $\begin{array}{l}\text { Information } \\
\text { retention is difficult } \\
\text { to define because } \\
\text { some knowledge is } \\
\text { subconscious } \\
\text { because everyone } \\
\text { has their own idea } \\
\text { of what's important } \\
\text { and an assignment } \\
\text { scenario demands } \\
\text { input, and working } \\
\text { with others gives } \\
\text { rise to knowledge } \\
\text { transfer. }\end{array}$ \\
\hline
\end{tabular}




\begin{tabular}{|c|c|c|c|c|}
\hline & $\begin{array}{l}\text { intended to add } \\
\text { to the awareness } \\
\text { of the } \\
\text { challenges } \\
\text { associated with } \\
\text { retaining } \\
\text { expertise and } \\
\text { apply it to } \\
\text { organisational } \\
\text { methods. }\end{array}$ & & & \\
\hline $\begin{array}{l}\text { (Chaudhuri et al., } \\
\text { 2020) }\end{array}$ & $\begin{array}{l}\text { The objective of } \\
\text { this research is } \\
\text { to find out how } \\
\text { much these } \\
\text { WLB policies } \\
\text { and programmes } \\
\text { can help } \\
\text { organisations } \\
\text { accomplish their } \\
\text { goals }\end{array}$ & $\begin{array}{l}\text { The current } \\
\text { thesis includes } \\
\text { Deery (2008) } \\
\text { as the basis for } \\
\text { an } \\
\text { examination of } \\
\text { India's } \\
\text { analytical } \\
\text { literature on } \\
\text { WLB and } \\
\text { employee } \\
\text { retention over } \\
\text { the last } \\
\text { decade. }\end{array}$ & 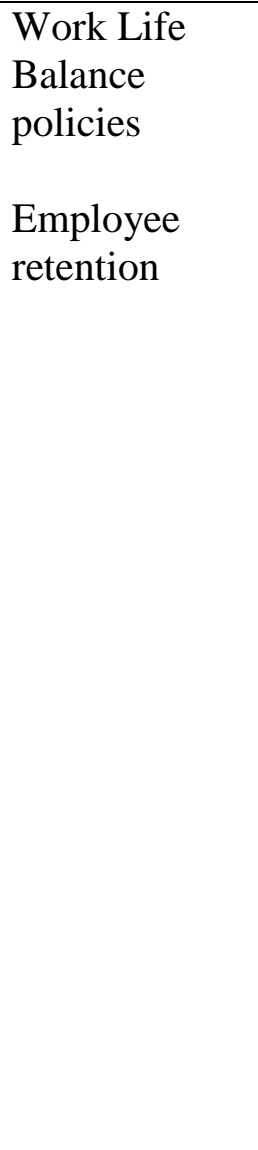 & $\begin{array}{l}\text { It has been found } \\
\text { that new research in } \\
\text { Indian organisations } \\
\text { appears to be in full } \\
\text { swing since } 2013 \text {. A } \\
\text { positivist paradigm } \\
\text { is the kind of } \\
\text { paradigm used in } \\
\text { the majority of this } \\
\text { type of research. } \\
\text { Information } \\
\text { technology (IT) and } \\
\text { business process } \\
\text { outsourcing (BPO) } \\
\text { industries also } \\
\text { benefitted greatly } \\
\text { from work-life } \\
\text { balance } \\
\text { programmes, but } \\
\text { banks have given } \\
\text { them their } \\
\text { employees even } \\
\text { more generous } \\
\text { support. }\end{array}$ \\
\hline $\begin{array}{l}\text { (Dhanpat et al., } \\
\text { 2019) }\end{array}$ & $\begin{array}{l}\text { The purpose of } \\
\text { this study is to } \\
\text { explore how } \\
\text { retention factors } \\
\text { affect the job } \\
\text { security of } \\
\text { public health } \\
\text { nurses in South } \\
\text { Africa. }\end{array}$ & $\begin{array}{l}\text { The thesis } \\
\text { employs a } \\
\text { cross-sectional } \\
\text { approach, } \\
\text { adheres to a } \\
\text { positivist } \\
\text { approach, and } \\
\text { relies on } \\
\text { quantitative } \\
\text { analysis. We } \\
\text { first started by } \\
\text { using pre- }\end{array}$ & $\begin{array}{l}\text { Employee } \\
\text { retention; } \\
\text { Training and } \\
\text { development; } \\
\text { Compensation } \\
\text { and benefits; } \\
\text { Supervisor } \\
\text { support; }\end{array}$ & $\begin{array}{l}\text { It was proven that } \\
\text { there is a correlation } \\
\text { between career } \\
\text { tenure and retention } \\
\text { variables. And } \\
\text { further, the research } \\
\text { found that } \\
\text { preparation and } \\
\text { advancement are the } \\
\text { most important for } \\
\text { the retention of jobs } \\
\text { in nursing. }\end{array}$ \\
\hline
\end{tabular}




\begin{tabular}{|c|c|c|c|c|}
\hline & & $\begin{array}{l}\text { existing } \\
\text { questionnaires } \\
\text { as a way to } \\
\text { gather data. To } \\
\text { pick a } \\
\text { convenience } \\
\text { sample, non- } \\
\text { probability } \\
\text { sampling was } \\
\text { used. } 202 \\
\text { questionnaires } \\
\text { were } \\
\text { circulated and } \\
\text { answers were } \\
\text { obtained from } \\
\text { three } \\
\text { Johannesburg } \\
\text { hospitals. The } \\
\text { questionnaire's } \\
\text { psychometric } \\
\text { properties } \\
\text { were tested by } \\
\text { virtue of their } \\
\text { precision and } \\
\text { the survey } \\
\text { takers' } \\
\text { agreement. } \\
\text { combining } \\
\text { descriptive } \\
\text { and inferential } \\
\text { statistics is } \\
\text { used to } \\
\text { examine data }\end{array}$ & $\begin{array}{l}\text { Work-life } \\
\text { balance; } \\
\text { Work } \\
\text { environment; } \\
\text { Job content } \\
\text { Career } \\
\text { advancement }\end{array}$ & \\
\hline $\begin{array}{l}\text { (Agus \& } \\
\text { Selvaraj, 2020) }\end{array}$ & $\begin{array}{l}\text { The aim of this } \\
\text { study is to } \\
\text { explore the } \\
\text { connection } \\
\text { between job } \\
\text { quality, the } \\
\text { desire to remain } \\
\text { in the private } \\
\text { healthcare } \\
\text { industry, and } \\
\text { hospital } \\
\text { employment } \\
\text { among }\end{array}$ & $\begin{array}{l}\text { Survey was } \\
\text { conducted on } \\
\text { a cross- } \\
\text { sectional basis } \\
\text { in this } \\
\text { research. The } \\
\text { most } \\
\text { important data } \\
\text { for this study } \\
\text { was gathered } \\
\text { by using self- } \\
\text { administered } \\
\text { questionnaires }\end{array}$ & $\begin{array}{l}\text { quality of work } \\
\text { life (QWL), } \\
\text { employee } \\
\text { commitment } \\
\text { the intention to } \\
\text { stay }\end{array}$ & $\begin{array}{l}\text { Job context was the } \\
\text { most important in } \\
\text { influencing the } \\
\text { respondents' } \\
\text { decision to stay, } \\
\text { accompanied by the } \\
\text { work environment, } \\
\text { the work place, and } \\
\text { personal context. } \\
\text { This study further } \\
\text { suggests that QL } \\
\text { has a major impact } \\
\text { on decision to }\end{array}$ \\
\hline
\end{tabular}




\begin{tabular}{|c|c|c|c|c|}
\hline & $\begin{array}{l}\text { Malaysian } \\
\text { nurses. }\end{array}$ & $\begin{array}{l}\text { with the } \\
\text { nurses from } \\
\text { Selang and } \\
\text { Kuala } \\
\text { Lumpur, } \\
\text { Malaysia, } \\
\text { Malaysia's } \\
\text { four state- } \\
\text { owned } \\
\text { hospitals as } \\
\text { respondents. } \\
\text { Around three } \\
\text { hundred } \\
\text { questionnaires } \\
\text { were issued, } \\
\text { and 202 of } \\
\text { them were } \\
\text { returned. The } \\
\text { results were } \\
\text { simple } \\
\text { correlations, } \\
\text { the } \\
\text { confirmatory } \\
\text { factor } \\
\text { analysis, and } \\
\text { the association } \\
\text { (SEM). }\end{array}$ & & $\begin{array}{l}\text { remain It follows, } \\
\text { because if workers } \\
\text { are content, the } \\
\text { employees' loyalty } \\
\text { will be greater, and } \\
\text { their desire to } \\
\text { remain in the } \\
\text { company will be } \\
\text { that much greater. }\end{array}$ \\
\hline $\begin{array}{l}\text { (Tews et al., } \\
2020)\end{array}$ & $\begin{array}{l}\text { The objective of } \\
\text { this analysis is } \\
\text { to examine the } \\
\text { impact of "fun } \\
\text { games," } \\
\text { "entertainment," } \\
\text { and "training" } \\
\text { on employee } \\
\text { turnover in } \\
\text { Europe. }\end{array}$ & $\begin{array}{l}\text { Regression } \\
\text { analysis was } \\
\text { used on a } \\
\text { survey of } 902 \\
\text { workers from } \\
\text { Belgium, } \\
\text { Germany, the } \\
\text { Netherlands, } \\
\text { and the } \\
\text { Netherlands } \\
\text { for an } \\
\text { assessment of } \\
\text { the impacts of } \\
\text { fun and } \\
\text { training } \\
\text { environment } \\
\text { on employee } \\
\text { turnover for } \\
\text { Belgium, }\end{array}$ & $\begin{array}{l}\text { Fun in the } \\
\text { workplace (fun } \\
\text { activities, } \\
\text { manager } \\
\text { support for fun } \\
\text { and co-worker } \\
\text { socializing) } \\
\text { Training } \\
\text { climate } \\
\text { (organizational } \\
\text { support, } \\
\text { manager } \\
\text { support and job } \\
\text { support) } \\
\text { antecedents of } \\
\text { turnover }\end{array}$ & $\begin{array}{l}\text { Community level } \\
\text { encouragement for } \\
\text { fun and friendly } \\
\text { activities proved } \\
\text { positive in regard to } \\
\text { employee turnover, } \\
\text { but no fun activities } \\
\text { had a significant } \\
\text { impact on co- } \\
\text { worker social } \\
\text { interaction. with } \\
\text { respect to } \\
\text { organisational } \\
\text { preparation, } \\
\text { however, this was } \\
\text { linked to person- } \\
\text { level work } \\
\text { engagement, but not } \\
\text { encouragement and }\end{array}$ \\
\hline
\end{tabular}




\begin{tabular}{|c|c|c|c|c|}
\hline & & $\begin{array}{l}\text { Germany. } \\
\text { Information } \\
\text { about the } \\
\text { amount of fun } \\
\text { and training } \\
\text { was collected } \\
\text { through } \\
\text { surveys, which } \\
\text { were } \\
\text { combined with } \\
\text { organisational } \\
\text { records on } \\
\text { productivity } \\
\text { data. }\end{array}$ & & commitment \\
\hline $\begin{array}{l}\text { (Matongolo et } \\
\text { al., 2018) }\end{array}$ & $\begin{array}{l}\text { The primary } \\
\text { objective of this } \\
\text { paper is to } \\
\text { investigate } \\
\text { empirically the } \\
\text { interplay } \\
\text { between } \\
\text { incentive policy, } \\
\text { people } \\
\text { orientation, and } \\
\text { employee } \\
\text { retention in } \\
\text { university and } \\
\text { corporate } \\
\text { settings in } \\
\text { Uganda. }\end{array}$ & $\begin{array}{l}\text { From } 218 \\
\text { respondents, } \\
\text { data were } \\
\text { collected for } \\
\text { two public } \\
\text { universities. } \\
\text { To identify } \\
\text { influences on } \\
\text { the variables, } \\
\text { both a } \\
\text { confirmatory } \\
\text { factor analysis } \\
\text { (CFA) and a } \\
\text { structural } \\
\text { equation } \\
\text { modelling } \\
\text { (SEM) were } \\
\text { employed. }\end{array}$ & $\begin{array}{l}\text { Employer } \\
\text { branding; } \\
\text { Reward } \\
\text { strategy; } \\
\text { People } \\
\text { orientedness; } \\
\text { Leadership } \\
\text { development; } \\
\text { talent retention } \\
\text { According }\end{array}$ & $\begin{array}{l}\text { The study found } \\
\text { that two out of three } \\
\text { of the four } \\
\text { important } \\
\text { dimensions for } \\
\text { employer branding; } \\
\text { incentive policy, } \\
\text { people orientation, } \\
\text { and leadership were } \\
\text { unchanged. }\end{array}$ \\
\hline $\begin{array}{l}\text { (Watson et al., } \\
\text { 2018) }\end{array}$ & $\begin{array}{l}\text { The main } \\
\text { purpose of this } \\
\text { research is to } \\
\text { recognise and to } \\
\text { study the } \\
\text { influence of } \\
\text { personal } \\
\text { inspiration and } \\
\text { loyalty on each } \\
\text { other. }\end{array}$ & $\begin{array}{l}\text { This is a well- } \\
\text { tested, large- } \\
\text { scale analysis } \\
\text { that measures } \\
\text { the personal } \\
\text { inspiration, } \\
\text { flow, and } \\
\text { loyalty of the } \\
\text { hotel and } \\
\text { restaurant } \\
\text { workers in the } \\
\text { UK. PLS- } \\
\text { SEM is } \\
\text { commonly }\end{array}$ & $\begin{array}{l}\text { Personal } \\
\text { motivation; } \\
\text { Commitment; } \\
\text { Group } \\
\text { differences: } \\
\text { length of } \\
\text { service, age } \\
\text { and gender; }\end{array}$ & $\begin{array}{l}\text { PLS-SEM enabled } \\
\text { us to identify } \\
\text { employees' flow and } \\
\text { also established the } \\
\text { relationship } \\
\text { between the degree } \\
\text { of flow and the } \\
\text { employee's drive, } \\
\text { and thus a direct } \\
\text { correlation between } \\
\text { drive and } \\
\text { engagement. Multi- } \\
\text { group research } \\
\text { discovered that }\end{array}$ \\
\hline
\end{tabular}




\begin{tabular}{|c|c|c|c|c|}
\hline & & $\begin{array}{l}\text { used for } \\
\text { qualitative or } \\
\text { quantitative } \\
\text { analyses. }\end{array}$ & & $\begin{array}{l}\text { longevity, personal } \\
\text { ambition, and } \\
\text { striving for flow } \\
\text { were more } \\
\text { important for older } \\
\text { workers who got } \\
\text { involved in } \\
\text { hospitality in their } \\
\text { youth for those who } \\
\text { had never worked in } \\
\text { the industry before, } \\
\text { compared to } \\
\text { employees who had } \\
\text { been in the industry } \\
\text { for fewer than five } \\
\text { years and those who } \\
\text { never got involved } \\
\text { in hospitality. There } \\
\text { are no major gaps in } \\
\text { the salaries of male } \\
\text { and female workers. }\end{array}$ \\
\hline $\begin{array}{l}\text { (Chang \& } \\
\text { Busser, 2020) }\end{array}$ & $\begin{array}{l}\text { They want to } \\
\text { explore the } \\
\text { retention issues } \\
\text { in the industry } \\
\text { by doing this } \\
\text { report. Based on } \\
\text { social } \\
\text { engagement, the } \\
\text { research looks at } \\
\text { a } \\
\text { Social/Structural } \\
\text { Contracting } \\
\text { model (SCF), } \\
\text { perceived } \\
\text { organisational } \\
\text { assistance } \\
\text { (POS), and job } \\
\text { fulfilment. }\end{array}$ & $\begin{array}{l}\text { It was } \\
\text { experimentally } \\
\text { derived by } \\
\text { conducting a } \\
\text { series of } \\
\text { structural } \\
\text { equation } \\
\text { simulation } \\
\text { tests on } 300 \\
\text { hotel workers } \\
\text { from the } \\
\text { United States. } \\
\text { Data were } \\
\text { acquired } \\
\text { through an } \\
\text { online survey } \\
\text { on Qualtrics' }\end{array}$ & $\begin{array}{l}\text { psychological } \\
\text { contract } \\
\text { fulfillment } \\
(\mathrm{PCF}) \text {; } \\
\text { perceived } \\
\text { organizational } \\
\text { support (POS); } \\
\text { thriving, career } \\
\text { satisfaction; } \\
\text { Career turnover } \\
\text { intention }\end{array}$ & $\begin{array}{l}\text { analytic findings } \\
\text { confirmed the vital } \\
\text { relationship } \\
\text { between working } \\
\text { background and } \\
\text { occupational well- } \\
\text { being Since the } \\
\text { PCF/POS expected, } \\
\text { employee } \\
\text { participation and } \\
\text { success had a } \\
\text { detrimental impact } \\
\text { on job aspirations, } \\
\text { overall satisfaction } \\
\text { with the PCF/POS, } \\
\text { and pursuit of other } \\
\text { plans had the same } \\
\text { relationship. }\end{array}$ \\
\hline $\begin{array}{l}\text { (DiPietro et al., } \\
\text { 2019) }\end{array}$ & $\begin{array}{l}\text { It is a quest to } \\
\text { investigate } \\
\text { independent fine } \\
\text { dining } \\
\text { establishments } \\
\text { to see how they } \\
\text { use more talent }\end{array}$ & $\begin{array}{l}\text { With data } \\
\text { gathered with } \\
\text { McCrack's } \\
\text { (1988) lengthy } \\
\text { interview } \\
\text { methodology, } \\
\text { we aim to }\end{array}$ & $\begin{array}{l}\text { Employee } \\
\text { turnover and } \\
\text { retention; } \\
\text { Quality of } \\
\text { work life }\end{array}$ & $\begin{array}{l}\text { Researches have } \\
\text { shown that people } \\
\text { have a high degree } \\
\text { of self-esteem while } \\
\text { working in the } \\
\text { kitchens, and the } \\
\text { atmosphere }\end{array}$ \\
\hline
\end{tabular}




\begin{tabular}{|c|c|c|c|c|}
\hline & $\begin{array}{l}\text { acquisition } \\
\text { strategies to } \\
\text { retain } \\
\text { employees. This } \\
\text { study concurs } \\
\text { with previously } \\
\text { mentioned } \\
\text { factors, most } \\
\text { notably TMA } \\
\text { and surf } \\
\text { experiences, } \\
\text { which have an } \\
\text { effect on } \\
\text { employee } \\
\text { engagement. }\end{array}$ & $\begin{array}{l}\text { determine how } \\
\text { and why staff } \\
\text { and } \\
\text { independent } \\
\text { restaurant } \\
\text { managers have } \\
\text { common } \\
\text { values. In this } \\
\text { experiment, } \\
\text { fourteen face- } \\
\text { to-to-face } \\
\text { interviews at } \\
\text { two FDRs are } \\
\text { combined to } \\
\text { notify the } \\
\text { findings This } \\
\text { research } \\
\text { employed an } \\
\text { inductive, } \\
\text { empirical } \\
\text { methodology. }\end{array}$ & & $\begin{array}{l}\text { motivates others to } \\
\text { do the best they can. } \\
\text { The independent } \\
\text { family-owned } \\
\text { company supports } \\
\text { workers to do well } \\
\text { while offering well- } \\
\text { being to the family } \\
\text { as a whole. A job } \\
\text { brings out the best } \\
\text { of people, which } \\
\text { therefore permits } \\
\text { them to do those } \\
\text { things that they are } \\
\text { passionate about. } \\
\text { The results of the } \\
\text { study show that an } \\
\text { understanding of } \\
\text { common values } \\
\text { between workers } \\
\text { and management } \\
\text { results in a more } \\
\text { lasting workforce. }\end{array}$ \\
\hline $\begin{array}{l}\text { (Chinyio et al., } \\
\text { 2018) }\end{array}$ & $\begin{array}{l}\text { The aim of this } \\
\text { research is to } \\
\text { find out how } \\
\text { these four } \\
\text { factors of } \\
\text { reward and pay } \\
\text { contribute to } \\
\text { public sector } \\
\text { construction } \\
\text { sector workers' } \\
\text { attraction, job } \\
\text { satisfaction, and } \\
\text { retention in } \\
\text { Jigawa, Nigeria. }\end{array}$ & $\begin{array}{l}\text { The Positivist } \\
\text { approach led } \\
\text { the study } \\
\text { where a } \\
\text { questionnaire } \\
\text { was created, } \\
\text { validated, and } \\
\text { used to select } \\
265 \text { members } \\
\text { of the general } \\
\text { population } \\
\text { from among } \\
\text { the strata } \\
\text { randomly } \\
\text { selected } \\
\text { persons. The } \\
\text { completion } \\
\text { rate was } 98 \\
\text { percent. } \\
\text { structural } \\
\text { equation } \\
\text { modelling was } \\
\text { used to }\end{array}$ & $\begin{array}{l}\text { allowances and } \\
\text { gratuity, } \\
\text { attracted to the } \\
\text { job by salary, } \\
\text { pension and } \\
\text { gratuity } \\
\text { remained in } \\
\text { their jobs }\end{array}$ & $\begin{array}{l}\text { It was seen that } \\
\text { Jigawa public } \\
\text { servants were } \\
\text { inspired by } \\
\text { allowances and } \\
\text { bonus payments, } \\
\text { choose their careers } \\
\text { because of them, } \\
\text { and did not leave } \\
\text { due to the benefits } \\
\text { of wage, pension } \\
\text { and retirement. It } \\
\text { was found to have a } \\
\text { large effect on all } \\
\text { the following four } \\
\text { variables: thanks to } \\
\text { which greatly } \\
\text { improved } \\
\text { everyone's attitudes }\end{array}$ \\
\hline
\end{tabular}




\begin{tabular}{|c|c|c|c|c|}
\hline & & $\begin{array}{l}\text { provide a } \\
\text { deeper } \\
\text { understanding } \\
\text { of the results }\end{array}$ & & \\
\hline $\begin{array}{l}\text { (Ayodele et al., } \\
2020 \text { ) }\end{array}$ & $\begin{array}{l}\text { In this research, } \\
\text { researchers are } \\
\text { investigating } \\
\text { both the social } \\
\text { dynamics of real } \\
\text { estate appraisers } \\
\text { as well as well } \\
\text { as } \\
\text { organisational } \\
\text { and individual } \\
\text { factors on their } \\
\text { roles. }\end{array}$ & $\begin{array}{l}\text { According to } \\
\text { the Lagos } \\
\text { State, Nigeria } \\
\text { estate } \\
\text { surveyors, } \\
\text { who had } \\
\text { responded to a } \\
\text { total of } 333 \\
\text { closed-ended } \\
\text { questionnaires, } \\
40.4 \% \text { were } \\
\text { appropriate for } \\
\text { study, } 333 \text { of } \\
\text { them had a } \\
\text { hardcopy } \\
\text { document } \\
\text { component } \\
\text { and } 124 \\
\text { (37.2\% of the } \\
\text { total) had a } \\
\text { computer- } \\
\text { generated } \\
\text { answer. The } \\
\text { frequencies, } \\
\text { percentage of } \\
\text { positive } \\
\text { results, one- } \\
\text { test result, and } \\
\text { ANOVA were } \\
\text { used to } \\
\text { analyse the } \\
\text { data. }\end{array}$ & $\begin{array}{l}\text { Age; } \\
\text { management } \\
\text { level; } \\
\text { professional } \\
\text { qualification; } \\
\text { Employee } \\
\text { retention; } \\
\text { Career } \\
\text { commitment; } \\
\text { Organisational } \\
\text { commitment; }\end{array}$ & $\begin{array}{l}\text { The results proved } \\
\text { that the men placed } \\
\text { a greater value on } \\
\text { their employment, } \\
\text { but women put their } \\
\text { careers first. } \\
\text { Besides, there was a } \\
\text { substantial } \\
\text { relationship } \\
\text { between gender and } \\
\text { organisational } \\
\text { engagement overall } \\
\text { This finding shows } \\
\text { that while } \\
\text { demographic } \\
\text { variables such as } \\
\text { age, management } \\
\text { rank, and year of } \\
\text { establishment have } \\
\text { a strong correlation } \\
\text { with job dedication, } \\
\text { academic factors } \\
\text { don't occupation, } \\
\text { and marital status } \\
\text { do not. }\end{array}$ \\
\hline (Sun et al., 2019) & $\begin{array}{l}\text { The purpose of } \\
\text { this paper is to } \\
\text { examine the role } \\
\text { of meaning of } \\
\text { work as a } \\
\text { linking } \\
\text { mechanism } \\
\text { between the } \\
\text { perception of } \\
\text { work context }\end{array}$ & $\begin{array}{l}\text { Job } \\
\text { hypotheses } \\
\text { were drawn } \\
\text { upon, leading } \\
\text { to an } \\
\text { integrated } \\
\text { research } \\
\text { model being } \\
\text { created the } \\
\text { survey was }\end{array}$ & $\begin{array}{l}\text { Social mission; } \\
\text { Shared vision; } \\
\text { Meaning of } \\
\text { work; }\end{array}$ & $\begin{array}{l}\text { For the sake of the } \\
\text { sake of social good, } \\
\text { meaning, the social } \\
\text { mission was largely } \\
\text { driven by common } \\
\text { meaning. There was } \\
\text { also a greater } \\
\text { positive correlation } \\
\text { between social } \\
\text { mission and sense in }\end{array}$ \\
\hline
\end{tabular}




\begin{tabular}{|c|c|c|c|c|}
\hline & $\begin{array}{l}\text { and turnover } \\
\text { intention within } \\
\text { the rarely } \\
\text { studied context } \\
\text { of social } \\
\text { enterprises. }\end{array}$ & $\begin{array}{l}\text { administered } \\
\text { to participants } \\
\text { who worked } \\
\text { full-time at } \\
114 \text { social } \\
\text { enterprises in } \\
\text { Korea for at } \\
\text { all. Statistical } \\
\text { and statistical- } \\
\text { mechanical } \\
\text { methods were } \\
\text { employed to } \\
\text { derive the } \\
\text { hypotheses } \\
\text { using a } \\
\text { procedure } \\
\text { known as } \\
\text { controlled } \\
\text { regression. }\end{array}$ & & $\begin{array}{l}\text { work when meaning } \\
\text { of work was } \\
\text { accompanied by a } \\
\text { group vision that the } \\
\text { writers discovered. }\end{array}$ \\
\hline $\begin{array}{l}\text { (Ströbel et al., } \\
\text { 2018) }\end{array}$ & $\begin{array}{l}\text { The aim of this } \\
\text { paper is to } \\
\text { determine the } \\
\text { influence of } \\
\text { team resources } \\
\text { on professional } \\
\text { athletes' } \\
\text { intentions. }\end{array}$ & $\begin{array}{l}\text { Qualitative } \\
\text { and } \\
\text { quantitative } \\
\text { analysis, } \\
\text { including } \\
\text { criteria for a } \\
\text { European } \\
\text { sports team, is } \\
\text { used in the } \\
\text { research. It } \\
\text { starts with } \\
\text { qualitative } \\
\text { research, } \\
\text { looking at } \\
\text { various } \\
\text { support } \\
\text { mechanisms in } \\
\text { a competitive } \\
\text { sport and } \\
\text { differentiating } \\
\text { financial } \\
\text { compensation } \\
\text { from it. } \\
\text { Second, an } \\
\text { analysis of } \\
\text { individual and } \\
\text { corporate }\end{array}$ & $\begin{array}{l}\text { Integration of } \\
\text { athletes' } \\
\text { families; } \\
\text { Organizational } \\
\text { support, } \\
\text { Non-monetary } \\
\text { incentives, } \\
\text { Professional } \\
\text { team sports }\end{array}$ & $\begin{array}{l}\text { Qualitative team } \\
\text { sports research } \\
\text { proved to identify } \\
\text { three significant } \\
\text { non-monetary } \\
\text { factors: second job } \\
\text { sponsorship, } \\
\text { alignment of } \\
\text { families, and } \\
\text { imaginative } \\
\text { problem solving. } \\
\text { This separate } \\
\text { research quantifies } \\
\text { how much ice } \\
\text { hockey, basketball, } \\
\text { and handball } \\
\text { players do as a } \\
\text { result of incentives. } \\
\text { Turnover purpose is } \\
\text { hurt by all three of } \\
\text { these motivators to } \\
\text { an equal degree, but } \\
\text { IOF has a greater } \\
\text { impact on younger } \\
\text { athletes. }\end{array}$ \\
\hline
\end{tabular}




\begin{tabular}{|c|c|c|c|c|}
\hline & & $\begin{array}{l}\text { rewards is } \\
\text { done on a } \\
\text { particular } \\
\text { sample } \\
\text { collection of } \\
\text { athletes using } \\
\text { a quantitative } \\
\text { means of } \\
\text { inquiry. And } \\
\text { finally, a } \\
\text { moderation } \\
\text { study gauges } \\
\text { the possibility } \\
\text { of negative } \\
\text { side effects } \\
\text { caused by age. }\end{array}$ & & \\
\hline $\begin{array}{l}\text { (Sumbal et al., } \\
\text { 2020) }\end{array}$ & $\begin{array}{l}\text { The thesis aims } \\
\text { to investigate } \\
\text { information loss } \\
\text { in a business } \\
\text { field that is } \\
\text { dependent on } \\
\text { three variables: } \\
\text { the risk of loss, } \\
\text { importance of } \\
\text { its loss, and an } \\
\text { assessment of } \\
\text { how each } \\
\text { knowledge } \\
\text { factor is in } \\
\text { relation to the } \\
\text { overall } \\
\text { objectives of the } \\
\text { business. }\end{array}$ & $\begin{array}{l}\text { A battery } \\
\text { processing } \\
\text { case study was } \\
\text { performed on } \\
\text { a multinational } \\
\text { corporation } \\
\text { from Hong } \\
\text { Kong. Semi- } \\
\text { structured } \\
\text { interviews } \\
\text { have been } \\
\text { completed and } \\
\text { studied by } \\
\text { CAQDAS } \\
\text { ATLAS. }\end{array}$ & $\begin{array}{l}\text { Layoffs; } \\
\text { Job change; } \\
\text { Retirement; } \\
\text { Immigration; } \\
\text { Knowledge of } \\
\text { relationships } \\
\text { and networks }\end{array}$ & $\begin{array}{l}\text { The results indicate } \\
\text { that career loss, } \\
\text { globalisation, } \\
\text { retirement, and } \\
\text { layoffs are all } \\
\text { independently } \\
\text { associated with } \\
\text { knowledge lack of } \\
\text { knowledge. the } \\
\text { critical areas of } \\
\text { information loss are } \\
\text { the customer and } \\
\text { supplier } \\
\text { relationships and } \\
\text { processes, } \\
\text { particularly as well } \\
\text { as the technical } \\
\text { Because you'll get } \\
\text { to use these areas of } \\
\text { expertise in future } \\
\text { ventures, it's } \\
\text { important to ensure } \\
\text { that they are } \\
\text { relevant and up to } \\
\text { date with company } \\
\text { strategy. }\end{array}$ \\
\hline $\begin{array}{l}\text { (Alferaih et al., } \\
\text { 2018) }\end{array}$ & $\begin{array}{l}\text { The primary aim } \\
\text { of this paper is } \\
\text { to explain the } \\
\text { position }\end{array}$ & $\begin{array}{l}\text { Employees at } \\
\text { a high-level } \\
\text { position in 5- } \\
\text { star hotels }\end{array}$ & $\begin{array}{l}\text { Talent } \\
\text { retention } \\
\text { Turnover; }\end{array}$ & $\begin{array}{l}\text { Help for the nine } \\
\text { hypotheses to } \\
\text { evaluate the } \\
\text { relationships was }\end{array}$ \\
\hline
\end{tabular}




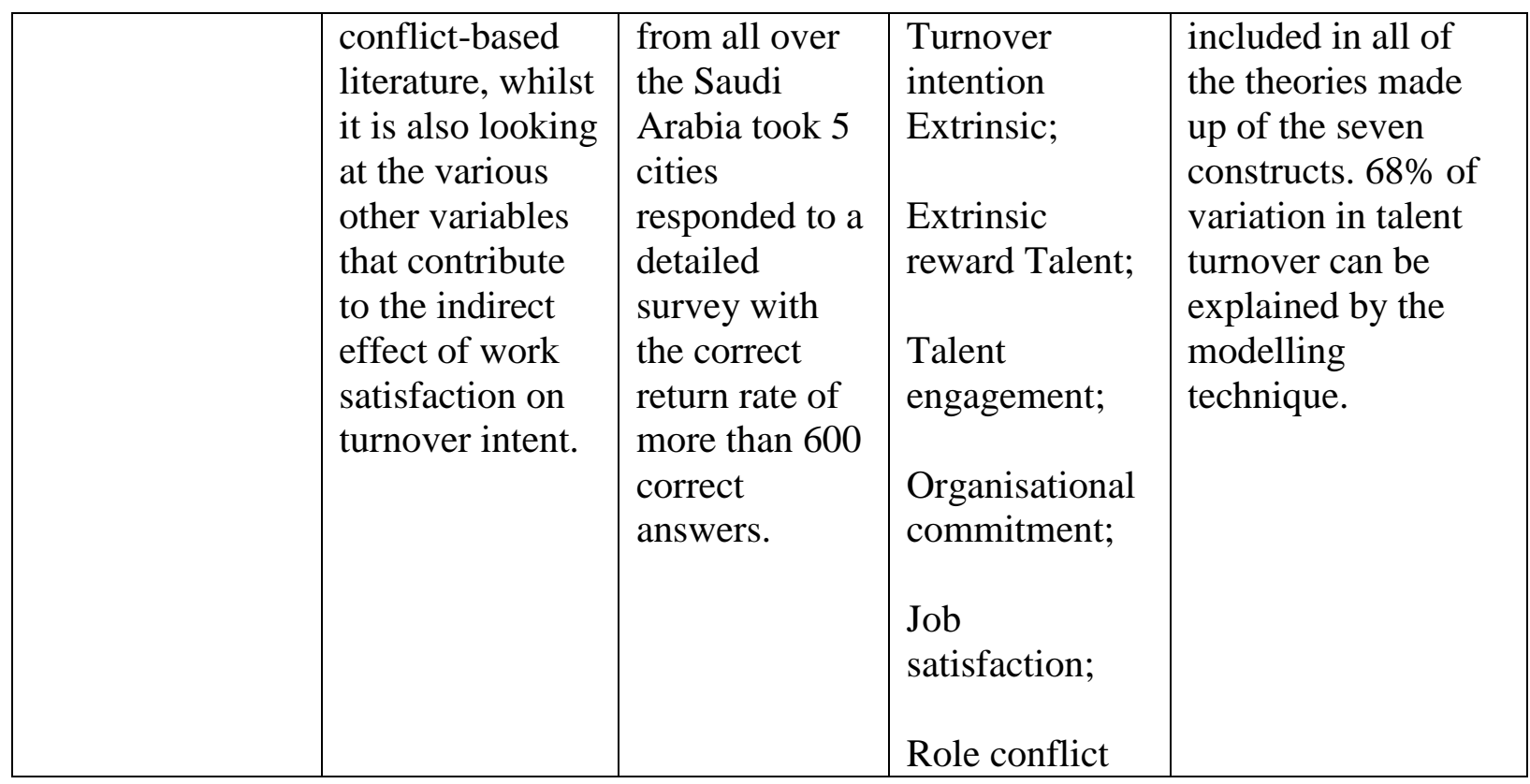

\section{IMPLICATIONS}

Theoretically, there is a dearth of evidence demonstrating how talent acquisition techniques aid in attracting high-potential workers. Despite the fact that talent management has a direct effect on attrition intentions, this article addresses the impact of talent management strategies on embedding high potential staff and resulting in lower turnover rates, which can serve as a research agenda for prospective talent management studies. An observational research that considers differences in talent management strategies and work embeddedness, as well as their impact on result variables such as attrition intentions, will provide further insight into the model, indicating the direction and intensity of these partnerships.

On a more specific level, this article urges human resource professionals to consider the importance of career embeddedness in the relationship between talent management and employee engagement, rather than relying only on talent retention activities. Additionally, the numerous propositions equip HR practitioners with insights on how to maximise employee engagement through talent management by focusing on different interventions that improve the connection, match, and sacrifice aspects of embeddedness, thus increasing employee retention rates.

\section{CONCLUSIONS}

This report outlined the various researchers' creative approaches to retaining employees in organisations. Any organization's primary concern is its ability to recruit, involve, and maintain the best employees. The organisation should implement a variety of techniques to improve workforce satisfaction, including the following: pay policies, job protection, leadership and supervision, career preparation and growth, alternate work schedules, working environments, flexible work hours, cultivating an engaged society, work-life balance, and improving labour welfare. The enterprises concentrated on intrinsic and extrinsic motivating factors that can help companies improve retention and reduce their high workforce vacancy rates. With the increasing need for companies to keep its best workers in the face of competition, the evaluation study's results indicate that such factors play a significant role in shaping employees' decisions to leave or stay with an organisation. Training and development, recognition/reward for superior success, 
a fair pay plan, and career protection are all examples of those variables. Only a systematic mix of intrinsic and extrinsic motivating factors has the potential to increase productivity and decrease the high rate of workforce attrition in our different organisations.

\section{REFERENCES}

Agus, A., \& Selvaraj, R. (2020). The mediating role of employee commitment in the relationship between quality of work life and the intention to stay. Employee Relations, 42(6), 1231-1248. https://doi.org/10.1108/ER-07-2019-0292

Al-Weshah, G. A. (2019). Towards internal marketing practices in enhancing job engagement: Practical evidence from Jordanian hospitals. International Journal of Pharmaceutical and Healthcare Marketing, 13(1), 40-56. https://doi.org/10.1108/IJPHM-11-2017-0063

Alferaih, A., Sarwar, S., \& Eid, A. (2018). Talent turnover and retention research: The case of tourism sector organisations in Saudi Arabia. Evidence-Based HRM, 6(2), 166-186. https://doi.org/10.1108/EBHRM-06-2017-0035

Arasanmi, C. N., \& Krishna, A. (2019). Employer branding: perceived organisational support and employee retention - the mediating role of organisational commitment. Industrial and Commercial Training, 51(3), 174-183. https://doi.org/10.1108/ICT-10-2018-0086

Ashraf, M. A. (2019). Influences of working condition and faculty retention on quality education in private universities in Bangladesh: An analysis using SEM. International Journal of Educational Management, 33(1), 149-165. https://doi.org/10.1108/IJEM-032018-0121

Ashraf, M. A. (2020). Demographic factors, compensation, job satisfaction and organizational commitment in private university: an analysis using SEM. Journal of Global Responsibility, 11(4), 407-436. https://doi.org/10.1108/jgr-01-2020-0010

Ayodele, T. O., Ekemode, B. G., Oladokun, S., \& Kajimo-Shakantu, K. (2020). The nexus between demographic correlates, career and organizational commitment: the case of real estate employees in Nigeria. Journal of Facilities Management, 18(5), 521-545. https://doi.org/10.1108/JFM-07-2020-0047

Buers, C., Karpinska, K., \& Schippers, J. (2018). Managers' retention decisions regarding young intermediate-level educated employees. International Journal of Manpower, 39(2), 254-268. https://doi.org/10.1108/IJM-05-2016-0114

Chang, W., \& Busser, J. A. (2020). Hospitality career retention: the role of contextual factors and thriving at work. International Journal of Contemporary Hospitality Management, 32(1), 193-211. https://doi.org/10.1108/IJCHM-10-2018-0831

Chaudhuri, S., Arora, R., \& Roy, P. (2020). Work-Life balance policies and organisational outcomes - a review of literature from the Indian context. Industrial and Commercial Training, 52(3), 155-170. https://doi.org/10.1108/ICT-01-2019-0003

Chinyio, E., Suresh, S., \& Salisu, J. B. (2018). The impacts of monetary rewards on public sector employees in construction: A case of Jigawa state in Nigeria. Journal of Engineering, Design and Technology, 16(1), 125-142. https://doi.org/10.1108/JEDT-122016-0098

Dhanpat, N., Manakana, T., Mbacaza, J., Mokone, D., \& Mtongana, B. (2019). Exploring retention factors and job security of nurses in Gauteng public hospitals in South Africa. African Journal of Economic and Management Studies, 10(1), 57-71. https://doi.org/10.1108/AJEMS-10-2018-0311

DiPietro, R., Martin, D., \& Pratt, T. (2019). Understanding employee longevity in independent 
fine dining restaurants: A grounded theory approach. International Journal of Contemporary Hospitality Management, 31(10), 4062-4085. https://doi.org/10.1108/IJCHM-10-2018-0869

Ewerlin, D., \& Süß, S. (2016). Dissemination of talent management in Germany: myth, facade or economic necessity? Personnel Review, 45(1), 142-160. https://doi.org/10.1108/PR08-2014-0174

Gandy, R., Harrison, P., \& Gold, J. (2018). Talent management in higher education: is turnover relevant? European Journal of Training and Development, 42(9), 597-610. https://doi.org/10.1108/EJTD-11-2017-0099

Gupta, V. (2019). Talent management dimensions and its relationship with Generation Y employee's intention to quit: an Indian hotel perspective. International Journal of Tourism Cities, 6(3), 583-600. https://doi.org/10.1108/IJTC-02-2019-0018

Jha, S. (2019). Determinants of employee retention: a moderated mediation model of abusive leadership and psychological empowerment. Industrial and Commercial Training, 51(78), 373-386. https://doi.org/10.1108/ICT-05-2019-0047

Marinakou, E., \& Giousmpasoglou, C. (2019). Talent management and retention strategies in luxury hotels: evidence from four countries. International Journal of Contemporary Hospitality Management, 31(10), 3855-3878. https://doi.org/10.1108/IJCHM-10-20180862

Matongolo, A., Kasekende, F., \& Mafabi, S. (2018). Employer branding and talent retention: perceptions of employees in higher education institutions in Uganda. Industrial and Commercial Training, 50(5), 217-233. https://doi.org/10.1108/ICT-03-2018-0031

Maurya, K. K., \& Agarwal, M. (2018). Organisational talent management and perceived employer branding. International Journal of Organizational Analysis, 26(2), 312-330. https://doi.org/10.1108/IJOA-04-2017-1147

Meyer, J. P., \& Smith, C. A. (2000). HRM Practices and Organizational Commitment: Canadian Journal of Administrative Sciences, 17(4), 319-331. https://doi.org/10.1108/IJOA-02-2020-2038

Mukherjee, B., Chandra, B., \& Singh, S. (2019). Talent retention in Indian public sector units (PSUs): an empirical investigation. Kybernetes, 49(6), 1783-1810. https://doi.org/10.1108/K-03-2019-0165

Nuhu, N. A., Baird, K., \& Appuhami, R. (2016). The association between the use of management accounting practices with organizational change and organizational performance. Advances in Management Accounting, 26, 67-98. https://doi.org/10.1108/S1474-787120150000026003

Rombaut, E., \& Guerry, M. A. (2020). The effectiveness of employee retention through an uplift modeling approach. International Journal of Manpower, 41(8), 1199-1220. https://doi.org/10.1108/IJM-04-2019-0184

Sablok, G., Stanton, P., Bartram, T., Burgess, J., \& Boyle, B. (2017). Human resource development practices, managers and multinational enterprises in Australia: Thinking globally, acting locally. Education and Training, 59(5), 483-501. https://doi.org/10.1108/ET-02-2016-0023

Sinclair-Maragh, G., Jacobs-Gray, N., \& Brown-Roomes, N. (2017). A case of talent management practices in motivating fast food service employees. Emerald Emerging Markets Case Studies, 7(3), 1-16. https://doi.org/10.1108/EEMCS-07-2016-0153

Steil, A. V., de Cuffa, D., Iwaya, G. H., \& Pacheco, R. C. dos S. (2020). Perceived learning 
opportunities, behavioral intentions and employee retention in technology organizations. Journal of Workplace Learning, 32(2), 147-159. https://doi.org/10.1108/JWL-04-20190045

Ströbel, T., Maier, C., \& Woratschek, H. (2018). How to reduce turnover intention in team sports? Effect of organizational support on turnover intention of professional team sports athletes. Sport, Business and Management: An International Journal, 8(2), 98-117. https://doi.org/10.1108/SBM-05-2017-0032

Su, T. S., Chen, C., Cui, X., Yang, C., \& Ma, W. (2020). Consistency at different levels: A meta-analytic examination of organizational trust and performance. Nankai Business Review International, Grant 220413736. https://doi.org/10.1108/NBRI-01-2020-0005

Sumbal, M. S., Tsui, E., Durst, S., Shujahat, M., Irfan, I., \& Ali, S. M. (2020). A framework to retain the knowledge of departing knowledge workers in the manufacturing industry. VINE Journal of Information and Knowledge Management Systems, 50(4), 631-651. https://doi.org/10.1108/VJIKMS-06-2019-0086

Sun, J., Lee, J. W., \& Sohn, Y. W. (2019). Work context and turnover intention in social enterprises: the mediating role of meaning of work. Journal of Managerial Psychology, 34(1), 46-60. https://doi.org/10.1108/JMP-11-2017-0412

Tafti, M. M., Mahmoudsalehi, M., \& Amiri, M. (2017). Critical success factors, challenges and obstacles in talent management. Industrial and Commercial Training, 49(1), 15-21. https://doi.org/10.1108/ICT-05-2016-0036

Tews, M. J., Hoefnagels, A., Jolly, P. M., \& Stafford, K. (2020). Turnover among young adults in the hospitality industry: examining the impact of fun in the workplace and training climate. Employee Relations, 43(1), 245-261. https://doi.org/10.1108/ER-11-2019-0432

Tian, H., Dogbe, C. S. K., Pomegbe, W. W. K., Sarsah, S. A., \& Otoo, C. O. A. (2020). Organizational learning ambidexterity and openness, as determinants of SMEs' innovation performance. European Journal of Innovation Management. https://doi.org/10.1108/EJIM-05-2019-0140

Watson, A. W., Taheri, B., Glasgow, S., \& O'Gorman, K. D. (2018). Branded restaurants employees' personal motivation, flow and commitment: The role of age, gender and length of service. International Journal of Contemporary Hospitality Management, 30(3), 1845-1862. https://doi.org/10.1108/IJCHM-02-2017-0075

Wikström, E., Eriksson, E., Karamehmedovic, L., \& Liff, R. (2018). Knowledge retention and age management - senior employees' experiences in a Swedish multinational company. Journal of Knowledge Management, 22(7), 1510-1526. https://doi.org/10.1108/JKM-092017-0442

Yogalakshmi, J. A., \& Supriya, M. V. (2020). Talent quotient: development and validation of a measurement scale. Journal of Management Development, 39(3), 306-323. https://doi.org/10.1108/JMD-03-2019-0075

\section{Copyrights}

Copyright for this article is retained by the author(s), with first publication rights granted to the journal. This is an open-access article distributed under the terms and conditions of the Creative Commons Attribution license (https://creativecommons.org/licenses/by/4.0) 